\title{
Blood meal as nitrogen source and its effect on disease severity on sweet corn
}

Karina de Jesus Egues Martins ${ }^{1}$

Camila Klem Miliati²

Antonio Luiz Viegas Neto 3

Lígia Maria Maraschi da Silva Piletti ${ }^{4}$

Rafael Pelloso de Carvalho ${ }^{5}$

Márcio Roberto Rigotte ${ }^{6}$

\section{Abstract}

A blood meal is a by-product of the meat processing industry and can be used as nitrogen fertilizer due to its minimum content of $10 \%$ Nitrogen. The objective of this work was to evaluate the effect of doses of blood meal, such as nitrogen fertilizer in topdressing, on the production components and the severity of diseases in sweet corn. The experiment was developed at the Federal Institute of Education, Science and Technology of Mato Grosso do Sul (IFMS), Ponta Porã campus, in a Quartzarenic Neosol. The experimental design used was randomized blocks with five treatments of blood meal doses of (0 kg ha-1; $48 \mathrm{~kg} \mathrm{ha}^{-1} ; 96 \mathrm{~kg} \mathrm{ha}^{-1} ; 120 \mathrm{~kg} \mathrm{ha}^{-1}$ and $144 \mathrm{~kg} \mathrm{ha}^{-1}$ ) and one treatment using urea for topdressing fertilization with $120 \mathrm{~kg} \mathrm{ha}^{-1}$ of $\mathrm{N}$. The experiment analyzed the severity of white spot on the tasseling and milk grain stages and also the production components: plant height, insertion height of the first ear, stalk diameter, length of the unhusked commercial ears, diameter of unhusked commercial ears, number of grain row, weight of husked commercial ears, weight of unhusked commercial ears and productivity in $\mathrm{kg} \mathrm{ha}^{-1}$. The use of blood meal was as efficient as the use of urea as a nitrogen fertilizer for doses starting from $48 \mathrm{~kg}$ ha-1, the maximum productivity was obtained when the dose of $112 \mathrm{~kg} \mathrm{ha}^{-1}$ of $\mathrm{N}$ blood meal was used. The severity of the white spot did not progress in treatments containing nitrogen fertilization in topdressing.

Keywords: Nitrogen fertilizer. Production components. White spot. Zea mays.

\section{Introduction}

In Brazil, approximately 36,000 hectares are cropped with sweet corn (Zea mays L.). Most of the production is destined for human consumption. This production is more adopted by small and medium farms, therefore it contributes in generating regional employment, improving logistics and food distribution (SANTOS et al., 2011).

To obtain high productivity in the corn crop, the adequate management of fertilization is necessary, especially the supply of nitrogen, which is the most absorbed and exported nutrient by the

1 Instituto Federal de Educação, Ciência e Tecnologia de Mato Grosso do Sul (IFMS). Engenheira Agrônoma. karina jem@hotmail.com.

2 IFMS. Engenheira Agrônoma. camila.miliati@hotmail.com.

3 IFMS. Professor EBTT. antonio.viegas@ifms.edu.br.

4 IFMS. Professor EBTT. ligia.piletti@ifms.edu.br.

5 IFMS. Professor EBTT. rafael.carvalho@ifms.edu.br.

6 IFMS. Professor EBTT. marcio.rigotte@ifms.edu.br. 
crop (SORATO et al., 2010). Nitrogen contributes to the production of corn since this element takes part in the structural function and activator of several enzymes. These contributions provide green and abundant vegetation, high foliage, and protein levels (MALAVOLTA, 2006).

A blood meal is a source of nitrogen fertilizer, which is a by-product generated in meat processing plants. It has a high nitrogen content $(\mathrm{N})$ when compared to other organic fertilizers, with a minimum content of $10 \% \mathrm{~N}$ (RIBEIRO; GUIMARÃES; ALVAREZ, 1999). Information on the use of this product as nitrogen fertilizer is scarce, despite the blood meal great importance in the production of animal diets, mainly for fish farming, due to its high added value residue, especially the number of proteins, with essential amino acids, vitamins, and minerals, and its high digestibility coefficient (RENUNCIO, 1997).

How the cultural management of a crop is conducted can influence its productivity, especially the nitrogen fertilization, which can also determine a greater or lesser predisposition to diseases (CARVALHO et al., 2013). Balanced fertilization, in addition to favoring production, can make the plant less susceptible to diseases and may even reduce its severity (HUBER; THOMPSON, 2007). According to Miguel et al. (2015), besides providing an increase in productivity, nitrogen fertilization is one of the cultural treatments that can minimize the effects of the main leaf diseases on plants. The white spot, caused by the fungus Phaeosphaeria maydis is one of the most important pathogens in the country due to the great geographic range in which it is found (MANFROI et al., 2016). In favorable conditions, the disease can cause a reduction in the photosynthetic rate of the plant causing its early dryness, and also a decrease in the period of grain filling, in the ear size, grain weight, and consequently corn productivity (MENDES; TEBALDI, 2011).

Lastly, the objective of this work was to evaluate the effect of doses of blood meal, as nitrogen fertilizer, on the production components and the severity of the white spot in sweet corn.

\section{Material and methods}

The experiment was carried out at the Federal Institute of Education, Science and Technology of Mato Grosso do Sul (IFMS), Ponta Porã, Mato Grosso do Sul campus, located on the BR 463 highway, km 14, 755nm above sea level. The soil in the area was classified as Quartzarenic Neosol (EMBRAPA, 2006) with a loam-sand texture containing $11.7 \%$ clay, $3.7 \%$ silt, and $84.6 \%$ sand. The climate is Aw-type, according to the Köppen-Geiger classification, with a rainy season in summer and a dry one in winter (PEEL; FINLAYSON; MCMAHON, 2007). The monthly average rainfall during the sweet corn cycle was $187.03 \mathrm{~mm}$.

The fertilization was carried out following the interpretation of the soil analysis (TABLE 1) according to Ribeiro, Guimarães, and Alvarez (1999), using $555 \mathrm{~kg} \mathrm{ha}^{-1}$ of Super Simple Phosphate, $100 \mathrm{~kg} \mathrm{ha}^{-1}$ potassium chloride, and $66 \mathrm{~kg} \mathrm{ha}^{-1}$ urea. The planting system used was the conventional one, with a heavy harrowing followed by a leveling. The corn cultivar used was the double hybrid AG 1051 from Agroceres, developed for the production of sweet corn and silage, which is recommended for the planting season and the producing regions of Mato Grosso do Sul.

The experimental design used in this work was the randomized block with four replicates. The treatments were set after the chemical analysis of the blood meal (TABLE 2). 
Table 1 - Chemical analysis of the soil in the experimental area in the $0-20 \mathrm{~cm}$ layer before treatment setting up and corn planting, Ponta Porã, MS, 2021.

\begin{tabular}{|c|c|c|c|c|c|c|c|c|c|}
\hline $\mathrm{pH}$ & O.M. & $\mathbf{P}$ & $\mathrm{K}$ & $\mathrm{Al}^{3+}$ & $\mathrm{Ca}$ & Mg & $\mathrm{H}+\mathrm{Al}$ & CTC $_{\text {Ph7 }}$ & V \\
\hline $\mathrm{CaCl}_{2}$ & $\mathrm{~g} \mathrm{dm}^{-3}$ & \multicolumn{2}{|c|}{$\mathrm{mg} \mathrm{dm}^{-3}$} & \multicolumn{5}{|c|}{ cmolc $\mathrm{dm}^{-3}$} & $\%$ \\
\hline 5.6 & 13.5 & 3.2 & 44 & 0.0 & 2.2 & 0.8 & 1.2 & 4.2 & 73 \\
\hline \multicolumn{10}{|c|}{ Texture $\mathrm{g} \mathrm{dm}^{-3}$} \\
\hline \multicolumn{4}{|c|}{ Sand } & \multicolumn{3}{|c|}{ Silt } & \multicolumn{3}{|c|}{ Clay } \\
\hline \multicolumn{4}{|c|}{847} & \multicolumn{3}{|c|}{37} & \multicolumn{3}{|c|}{117} \\
\hline
\end{tabular}

Source: Elaborated by the authors (2021).

Table 2 - Characterization of macronutrient, carbon/nitrogen rate, $\mathrm{pH}$, and micronutrients of blood meal, Ponta Porã, MS, 2021.

\begin{tabular}{|c|c|c|c|c|c|c|c|}
\hline \multicolumn{6}{|c|}{ Macronutrients } & \multirow[t]{2}{*}{ O.C. $/ \mathrm{N}$} & \multirow[t]{2}{*}{$\mathrm{pH}$} \\
\hline $\mathbf{N}$ & $\mathrm{P}_{2} \mathrm{O}_{5}$ & $\mathrm{~K}_{2} \mathrm{O}$ & $\mathrm{Ca}$ & Mg & $\mathbf{S}$ & & \\
\hline \multicolumn{8}{|c|}{$\%$} \\
\hline 12.57 & 0.14 & 0.78 & 0.07 & 0.01 & 0.5 & 3.12 & 6.7 \\
\hline \multicolumn{8}{|c|}{ Micronutrients } \\
\hline B & $\mathrm{Cu}$ & $\mathrm{Fe}$ & $M n$ & Mo & $\mathrm{Na}$ & $\mathrm{Ni}$ & $\mathrm{Zn}$ \\
\hline \multicolumn{8}{|c|}{$\mathrm{mg} / \mathrm{dm}^{3}$} \\
\hline N.D & 273.4 & 2346 & 4.59 & N.D & 8146 & 15.6 & 286.5 \\
\hline
\end{tabular}

Source: Elaborated by the authors (2021).

This experiment used five different doses of blood meal which corresponded to $0 \%, 40 \%$, $80 \%, 100 \%$, and $120 \%$ referring to the total $\mathrm{N}$ amount required for the topdressing fertilization equivalent to $120 \mathrm{~kg} \mathrm{ha}^{-1} \mathrm{~N}$. Quantitatively, these doses were equivalent to $0 \mathrm{~kg} \mathrm{ha}^{-1}, 381.90 \mathrm{~kg} \mathrm{ha}^{-1}$; $763.72 \mathrm{~kg} \mathrm{ha}^{-1} ; 954.66 \mathrm{~kg} \mathrm{ha}^{-1}$ and $1145.58 \mathrm{~kg} \mathrm{ha}^{-1}$ of blood meal, which contained $0 \mathrm{~kg} \mathrm{ha}^{-1}$, $48 \mathrm{~kg} \mathrm{ha}^{-1}, 96 \mathrm{~kg} \mathrm{ha}^{-1}, 120 \mathrm{~kg} \mathrm{ha}^{-1}$ and $144 \mathrm{~kg} \mathrm{ha}^{-1} \mathrm{~N}$ respectively and treatment using urea as a standard topdressing nitrogen fertilizer, in which $100 \%$ of the required amount of nitrogen was used, totaling 6 treatments. The experimental plots consisted of four rows of 6 meters, with a spacing of $0.9 \mathrm{~m}$ between rows, considering as a useful area only the two central lines for data collection. The plant population used in the experiment was $55,000 \mathrm{ha}^{-1}$.

To analyze the production components of sweet corn, ten plants from the useful area were measured, from the milky grain (R3) to the dough (R4) stage (RITCHIE; HANWAY; BENSON, 1993). Also, the plant height $(\mathrm{PH})$, the height of the plant stalk to the flag leaf, the height of the insertion of the first ear $(\mathrm{IH})$ were measured using a ruler, and the stalk diameter (SD) measured in the middle of the second stem internode using a digital caliper. To check the characteristics of the ears, 10 ears were manually harvested from the useful area of the plot. Afterward, the length of the unhusked commercial ears (UCE) was determined with the aid of a measuring tape from the base of the ear to its end; the diameter of husked commercial ears (HCED) was measured from the middle of the ear using a digital caliper; the number of rows of grains (GR) was set based on the visual count and the weight of commercial husked ears (CHEW) and weight of unhusked commercial ears (UCEW) was determined using a scale, considering the commercial ears those that had a length greater than $15 \mathrm{~cm}$ and $3 \mathrm{~cm}$ in diameter and from these, the productivity (PROD) was obtained in $\mathrm{kg} \mathrm{ha}^{-1}$ of unhusked ears. 
Assessments on the leaf disease severity were carried out in the VT stages, which consist of the tasseling and R3 at the milky grain stage. For these evaluations, the leaves were randomly selected within the useful portion, observing a leaf at the ear insertion height for visual analysis from the diagrammatic scale to assess the severity of the white spot in the percentage of the injured leaf area, shown by Sachs et al. (2011) and later, evaluations of the area under the disease progress curve (AUDPC) were carried out.

Data on production components, severity, and AUDPC were subjected to analysis of variance and when significant, regression analysis and Dunnet test at $5 \%$ probability were performed for comparisons with the urea standard dose.

\section{Results and discussion}

The analysis on the data on plant height, ear insertion height, stalk diameter, and diameter of the commercial ear showed that there was no significant difference by the test of Dunnett at $5 \%$ probability (TABLE 3 ) in comparison to the control treatment with the use of urea as topdressing nitrogen fertilization, that is, regardless the nitrogen dose used as blood meal, the treatment did not affect these production components.

Table 3 - Means of Sweet corn production component according to blood meal (BM) doses for plant height $(\mathrm{PH})$, insertion height of the first ear (EH), and stalk diameter (DC). Ponta Porã, MS, 2021.

\begin{tabular}{cccc}
\hline $\begin{array}{c}\text { BM doses } \\
\left(\mathbf{k g ~ h a}^{-1} \mathbf{N}\right)\end{array}$ & PH $(\mathbf{m})$ & EH $(\mathbf{m})$ & SD $(\mathbf{m m})$ \\
\hline 0 & $1.49^{\mathrm{ns}}$ & $0.78^{\mathrm{ns}}$ & $20.42^{\mathrm{ns}}$ \\
48 & $1.66^{\mathrm{ns}}$ & $0.92^{\mathrm{ns}}$ & $23.73^{\mathrm{ns}}$ \\
96 & $1.65^{\mathrm{ns}}$ & $0.93^{\mathrm{ns}}$ & $24.21^{\mathrm{ns}}$ \\
120 & $1.67^{\mathrm{ns}}$ & $0.96^{\mathrm{ns}}$ & $24.40^{\mathrm{ns}}$ \\
144 & $1.61^{\mathrm{ns}}$ & $0.94^{\mathrm{ns}}$ & $23.66^{\mathrm{ns}}$ \\
\hline Urea 120 & 1.66 & 0.94 & 24.94 \\
\hline
\end{tabular}

ns not different from the control by the test of Dunnett at $5 \%$ probability.

Source: Elaborated by the authors (2021).

For the length of the commercial ear, the weight of husked and unhusked ear, and the number of grain rows (TABLE 4), it was found that all doses of blood meal had no difference concerning fertilization with urea, indicating that it does not depend on the use of the other doses of blood meal, therefore showing that these results are as efficient as the use of urea, thus demonstrating the efficiency of this fertilization.

The comparison between $\mathrm{N}$ doses and blood meal revealed a significant effect for commercial ear length, husked and unhusked ear weight, and the number of grain rows. No significant effect was found for the other production components (FIGURE 1). 
Table 4 - Means of the sweet corn production components according to the doses of blood meal (BM) for the characteristics of productivity (PROD), length of the commercial ear (CEL), ear diameter (CED), the weight of the husked commercial ear (CHEW), the weight of the unhusked commercial ear (UCEW), and the number of grain rows (ROW). Ponta Porã, MS, 2021

\begin{tabular}{ccccccc}
\hline $\begin{array}{c}\text { BM Doses } \\
\left.\mathbf{k g ~ h a}^{-1} \mathbf{d e ~} \mathbf{N}\right)\end{array}$ & $\begin{array}{c}\text { PROD } \\
\left(\mathbf{k g ~ h a}^{-1}\right)\end{array}$ & $\begin{array}{c}\text { CEL } \\
(\mathbf{c m})\end{array}$ & $\begin{array}{c}\text { CED } \\
(\mathbf{m m})\end{array}$ & $\begin{array}{c}\text { CHEW } \\
(\mathbf{g})\end{array}$ & $\begin{array}{c}\text { UCEW } \\
(\mathbf{g})\end{array}$ & $\begin{array}{c}\text { ROW } \\
\text { (un) }\end{array}$ \\
\hline 0 & $690.5^{*}$ & $16.40^{*}$ & $42.63^{\text {ns }}$ & $217.4^{*}$ & $155.4^{*}$ & $14.75^{*}$ \\
48 & $932.8^{\text {ns }}$ & $18.36^{\text {ns }}$ & $45.76^{\text {ns }}$ & $289.6^{\text {ns }}$ & $209.9^{\text {ns }}$ & $15.89^{\text {ns }}$ \\
96 & $906.1^{\text {ns }}$ & $18.72^{\text {ns }}$ & $44.51^{\text {ns }}$ & $288.8^{\text {ns }}$ & $203.9^{\text {ns }}$ & $15.70^{\text {ns }}$ \\
120 & $1045.6^{\text {ns }}$ & $19.78^{\text {ns }}$ & $47.03^{\text {ns }}$ & $338.0^{\text {ns }}$ & $235.3^{\text {ns }}$ & $16.10^{\text {ns }}$ \\
144 & $1006.3^{\text {ns }}$ & $18.73^{\text {ns }}$ & $46.73^{\text {ns }}$ & $303.7^{\text {ns }}$ & $226.4^{\text {ns }}$ & $15.87^{\text {ns }}$ \\
\hline Urea 120 & 978.9 & 19.22 & 45.89 & 320.6 & 220.3 & 15.90 \\
\hline
\end{tabular}

Means followed by $(*)$ are different from the control by the test of Dunnet at $5 \%$ probability.

Means followed by ( ${ }^{\text {ns }}$ ) do not differ from the control by the test of Dunnett at $5 \%$ probability.

Source: Elaborated by the authors (2021).

Figure 1 - Regression of mean values of (A) commercial ear length (B) number of grain rows (C) weight of husked commercial ear (D) weight of unhusked commercial ear (E) and productivity according to $\mathrm{N}$ doses using blood meal as nitrogen fertilizer, Ponta Porã-MS, 2019.
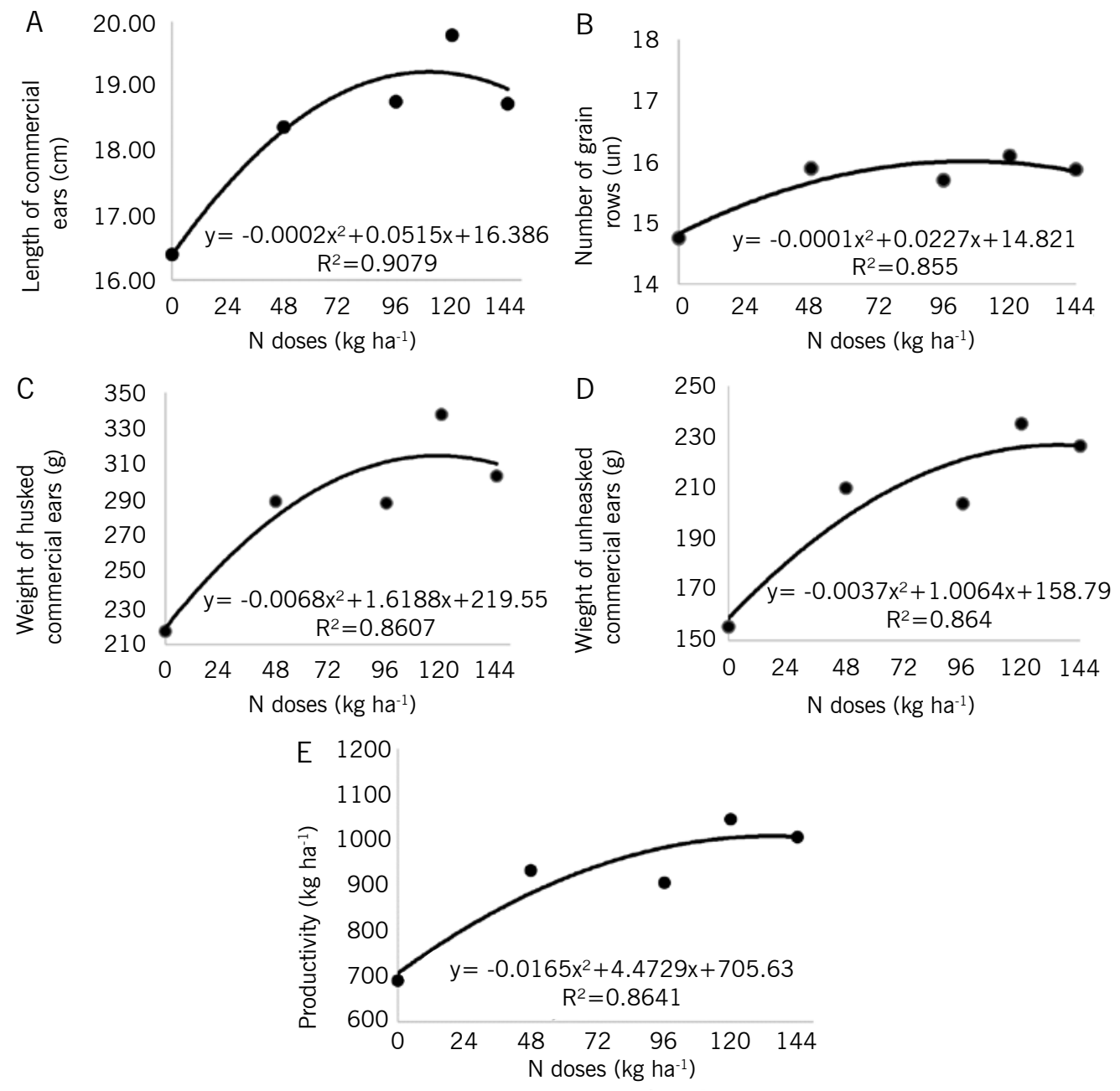

*: equation significant at $5 \%$ probability by the $\mathrm{F}$ test.

Source: Elaborated by the authors (2021). 
The maximum value for commercial ear length was $19.7 \mathrm{~cm}$ with a dose of $128 \mathrm{~kg} \mathrm{ha}^{-1} \mathrm{~N}$. According to Kappes et al. (2009), the average ear length, despite being a characteristic of high heritability and less dependence on the environment, is one of the production components that can directly interfere in the number of grains per row and consequently will affect corn productivity.

Pereira Filho and Cruz (2002) stated that the ideal ear length to meet both the interests of the filling industry and the production for fresh use is close to $20 \mathrm{~cm}$, a value very close to the maximum length to be obtained with the fertilization of $128 \mathrm{~kg}^{-1} \mathrm{~N}$ of the blood meal.

The largest number of grain rows was obtained using topdressing fertilization containing $113 \mathrm{~kg} \mathrm{ha}^{-1}$ $\mathrm{N}$ blood meal, with ears containing 16-grain rows. According to Fancelli and Dourado Neto (2000), the number of grain rows is defined in the V8 stage, a phase in which the nutrient availability, especially $\mathrm{N}$, is very important as this moment is of greater demands for this nutrient by the plant, thus emphasizing the importance of the correct management of nitrogen fertilization and the efficient use of blood meal.

The maximum weight of the husked and unhusked commercial ear was $315.9 \mathrm{~g}$ and $227.2 \mathrm{~g}$ obtained by applying $119 \mathrm{~kg}^{-1}$ and $136 \mathrm{~kg} \mathrm{ha}^{-1} \mathrm{~N}$ of blood meal, respectively. The average increases in-ear weight resulting from the application of $\mathrm{N}$ were $45.2 \%$ in husked ears and $46.3 \%$ for unhusked ears, when compared to the dose of $0 \mathrm{~kg} \mathrm{ha}^{-1} \mathrm{~N}$. This behavior was also observed by Freire et al. (2010), who found an increasing trend in weight of husked ear according to the increment of $\mathrm{N}$, in which higher doses of nitrogen provided greater volume of straw as this nutrient is directly linked with the growth and vegetative development, which will also affect the production of sweet corn ears due to increases in the average cob weights.

According to Damasceno et al. (2010), the weight of husked ears is very important for the commercialization of sweet corn, which is traded with the husk due to its culinary use since the consumer always tends to choose the largest and heaviest ears, both for consumption in fresh form and for the industry.

Nitrogen doses significantly influenced the increase in productivity, its production peak was $1027 \mathrm{~kg} \mathrm{ha}^{-1}$ of unhusked ears using the dose of $113 \mathrm{~kg} \mathrm{ha}^{-1}$ (FIGURE 1). Thus, the use of blood meal was as efficient as the use of urea as a nitrogen source. Freire et al. (2010) reported that because of the particularities of $\mathrm{N}$, the dose recommendations for crops are based on response curves obtained locally, depending on the mineralization rate, the organic matter content, and the leaching of nitrate in the soil, and, in particular, due to the amount of rainfall in the period of its conduction.

Regarding AUDPC, no difference was found between nitrogen doses when compared to the control treatment using urea as a source of nitrogen in topdressing (TABLE 5).

According to Silva (2002), the establishment of the disease on the plant after reaching the stage of maturation does not cause significant damage, so the effect of the disease on production varies according to when the plant was infected. Regarding white spot, Godoy et al. (2001) observed that only the visual quantification of the severity of the disease cannot present an exact indication of the effect of the pathogen on the photosynthetic content of the host, since phytosanitary efficacy is reduced not only in the injured tissue but also in parts of the remaining green tissue of the infected leaf.

For the severity of the disease, a significant difference was observed in the control treatment at the R3 stage (TABLE 5), in which the topdressing nitrogen fertilization had not been carried out, leading to an increase in the severity of the white spot. According to Durães et al. (2004), the use of high concentrations of fertilizer, such as $200 \mathrm{~kg} \mathrm{ha}^{-1}$ of nitrogen, resulted in a decrease in the 
incidence of the disease, which is also confirmed by the work of Corrêa et al. (2007) in which they emphasized that $\mathrm{N}$ interferes with the severity of the white spot.

Table 5 - Means of severities and AUDPC were analyzed in Sweet corn according to the blood meal (FS) and urea doses. Ponta Porã-MS, 2019.

\begin{tabular}{cccc}
\hline BM doses $\left(\mathbf{k g ~ h a}^{-1} \mathbf{N}\right)$ & Severity at VT stage (\%) & Severity at R3 (\%) & AUDPC (\%) \\
\hline 0 & $1.00^{\text {ns }}$ & $2.05^{*}$ & $50.4^{\text {ns }}$ \\
48 & $0.9^{\text {ns }}$ & $1.725^{\text {ns }}$ & $47.1^{\text {ns }}$ \\
96 & $0.9^{\text {ns }}$ & $1.675^{\text {ns }}$ & $44.2^{\text {ns }}$ \\
120 & $0.9^{\text {ns }}$ & $1.25^{\text {ns }}$ & $35.6^{\text {ns }}$ \\
144 & $0.9^{\text {ns }}$ & $1.25^{\text {ns }}$ & $39.6^{\text {ns }}$ \\
\hline Urea 120 & 0.9 & 1.15 & 28.8 \\
\hline
\end{tabular}

Means followed by $\left({ }^{*}\right)$ are different from the control by the test of $5 \%$ probability.

Means followed by ${ }^{\left({ }^{n s}\right)}$ are not significant.

Source: Elaborated by the authors (2021).

\section{Conclusion}

The use of blood meal in topdressing fertilization in sweet corn crop produces results similar to urea from the dose of $48 \mathrm{~kg} \mathrm{ha}^{-1} \mathrm{~N}$. The maximum yield was obtained using $112 \mathrm{~kg} \mathrm{ha}^{-1} \mathrm{~N}$ of blood meal in topdressing.

The corn crop responds positively to the increase in the dose of $\mathrm{N}$ using blood meal for ear length, husked ear weight, unhusked ear weight rows of commercial ear grains, and yield.

There was no influence of blood meal for the area below the white spot disease progress curve in the corn Crop.

\section{Farinha de sangue como fonte nitrogenada e seu efeito sobre a severidade de doenças no milho-verde}

\section{Resumo}

A farinha de sangue é um subproduto de frigoríficos e pode ser utilizada como adubo nitrogenado devido ao seu teor mínimo de $10 \%$ de nitrogênio. 0 objetivo deste trabalho foi avaliar o efeito de doses de farinha de sangue, como adubo nitrogenado em cobertura, sobre os componentes de produção e a severidade de doenças no milho-verde. O experimento foi desenvolvido no IFMS, Campus Ponta Porã, num Neossolo Quartzarênico. O delineamento experimental utilizado foi de blocos ao acaso, com cinco tratamentos de doses de farinha de sangue de $\left(0 \mathrm{~kg} \mathrm{ha}^{-1} ; 48 \mathrm{~kg} \mathrm{ha}^{-1} ; 96 \mathrm{~kg} \mathrm{ha}^{-1} ; 120 \mathrm{~kg} \mathrm{ha}^{-1} \mathrm{e}\right.$ $144 \mathrm{~kg} \mathrm{ha}^{-1}$ ) e um tratamento utilizando ureia para adubação em cobertura com $120 \mathrm{~kg} \mathrm{ha}^{-1} \mathrm{de} \mathrm{N}$. Foram analisadas a severidade de mancha branca nos estádios de pendoamento e grão leitoso, a avaliação dos componentes de produção: altura de planta, altura da inserção da primeira espiga, diâmetro do colmo, comprimento das espigas comerciais despalhadas, diâmetro de espigas comerciais 
despalhadas, número de fileiras de grãos, peso de espigas comerciais empalhadas, peso de espigas comerciais despalhadas e produtividade em $\mathrm{kg} \mathrm{ha}^{-1}$. A utilização da farinha de sangue se mostrou tão eficiente quanto o uso da ureia como adubo nitrogenado para as doses a partir de $48 \mathrm{~kg} \mathrm{ha}^{-1}$, a produtividade máxima foi obtida quando utilizada a dose de $112 \mathrm{~kg} \mathrm{ha}^{-1}$ de $\mathrm{N}$ de farinha de sangue em cobertura. A severidade da mancha branca não progrediu em tratamentos contendo a adubação nitrogenada em cobertura.

Palavras-chave: Zea mays. Adubo nitrogenado. Componentes de produção. Mancha branca.

\section{References}

CARVAlHO, D. O.; POZZA, E. A.; CASElA, C. R.; COSTA, R. V.; POZZA, A. A. A.; CARVAlHO, C. O. Adubação nitrogenada e potássica na severidade da antracnose em dois cultivares de milho. Revista Ceres, Viçosa, v. 60, n. 3, p. 380-387, 2013. Disponível em: https://www.scielo.br/scielo. php?script=sci_arttext\&pid=S0034-737X2013000300011. Acesso em: 29 jun. 2020.

DAMASCENO, T. M.; WINDER, A. R. daS.; NOGUEIRA, J. C. M.; DAMASCENO, M. M.; MENDES, J. C. da F.; DALLAPORTA, L. N. Influência do espaçamento de plantio de milho na produtividade de silagem. XXVIII Congresso Nacional de Milho e Sorgo, Goiânia, Goiás, 2010.

DURÃES, F. O. M.; MAGALHÃES, P. C.; MARRIEL, I. E.; GAMA, E. G.; CASELA, C. R.; OLIVEIRA, A. C.; CANTÃO, F. R. O. Caracterização de genótipos para uso e eficiência em de nitrogênio em milho e influência da adubação nitrogenada sobre a incidência e severidade de da mancha foliar de maydis. Sete Lagoas: Embrapa Milho e Sorgo, p.8, 2004.

EMBRAPA. Centro Nacional de Pesquisa de Solos. Sistema Brasileiro de Classificação de Solos. 2. ed. Rio de Janeiro: Embrapa Solos, 2006.

FANCELLI, A. L.; DOURADO NETTO, D. Produção de milho. Guaíba: Agropecuária, p. 320, 2000.

FREIRE, F. M.; VIANA, M. C. M.; MASCARENHAS, M. H. T.; PEDROSA, M. W.; COELHO, A. M.; ANDRADE, C. L. T. de. Produtividade econômica e componentes da produção de espigas verdes de milho em função da adubação nitrogenada. Revista Brasileira de Milho e Sorgo, v. 9, n. 3, p. 213-222, 2010.

GODOY, C. V.; AMORIM, L.; BERGAMIN FILHO, A. Alterações na fotossíntese e na transpiração de folhas de milho infectadas por Phaeosphaeria maydis. Fitopatologia Brasileira, Brasília, v. 26, p. 209-215, 2001

HUBER, D. M., THOMPSON, A. Nitrogen and plant disease. In: Nutrition mineral and plant disease. The American Phytopathological Society. Saint Paul. v. 1, p. 31-44, 2007. Disponível em: https:// www.researchgate.net/publication/284757533_Nitrogen_and_plant_disease_In_Mineral_nutrition_ and_plant_disease_Eds_LE_Datnoff_WH_Elmer_DM_Huber_The_American_Phytopathological_ Society_St_Paul_Minnesota. Acesso em: 29 jun. 2020. 
KAPPES, C.; CARVALHO, M. A. C. de.; YAMASHITA, O. M.; SILVA, J. A. N. da. KWIATKOWSKI, A.; CLEMENTE, E. Características do milho doce (Zea mays L.) para industrialização. Revista Brasileira de Tecnologia Agroindustrial, 2007.

MALAVOLTA, E. Manual de nutrição mineral de plantas. Piracicaba: Editora Ceres, 2006. 631p.

MANFROI, E.; LANGHINOTTI, C.; DANELLI, A.; PARIZE, G. Controle químico de doenças foliares e rendimento de grãos na cultura do milho. Revista Brasileira de Milho e Sorgo, Sete Lagoas, v. 15, n. 2, p. 357-365, 2016. Disponível em: http://rbms.cnpms.embrapa.br/index.php/ojs/article/view/ 511/pdf_472. Acesso em: 29 jun. 2020.

MENDES, L. S.; TEBALDI, N. D. Pantoea ananatis: importância, isolamento, cultivo em meio de cultura, inoculação, sobrevivência, disseminação, penetração, colonização e controle para cultura do milho (Zea mays L.). Revisão Anual de Patologia de Plantas, v. 19, p. 386-399, 2011.

MIGUEL, T. A.; TAKAHASHI, H. W.; BERND, L. P.; MONTAGNER, T.; BORDINI, J. G.; OMORI, A. M.; HIROOKA, E. Y.; ONO, E. Y. S. Efeitos da fertilização nitrogenada na contaminação de milho por fungos e fumonisinas. Biosaúde, Londrina, v. 17, n. 1, 2015.

PEEL, M. C.; FINLAYSON, B. L.; MCMAHON, T. A. Updated world map of the Köppen-Geiger climate classification. Hydrology and earth system sciences discussions, v. 4, n. 2, p. 439-473, 2007. Disponível em: https://www.hydrol-earth-syst-sci.net/11/1633/2007/. Acesso em: 29 jun. 2020.

PEREIRA FILHO, I. A.; CRUZ, J. C. Cultivares de milho para o consumo verde. Sete Lagoas: Embrapa CNPMS. Circular técnica n. 15, 2002.

RENUNCIO, A. Avaliação de métodos de coleta de sangue em pequenos abatedouros do estado de Santa Catarina visando sua valorização para o consumo humano. 1997. 45 p. Dissertação (Mestrado). Universidade Federal de Santa Catarina.

RIBEIRO, A. C.; GUIMARÃES, P. T. G.; ALVAREZ, V. H. Recomendações para o uso de corretivos e fertilizantes em Minas Gerais: 5. Aproximação. Comissão de Fertilidade do Solo do Estado de Minas Gerais, 1999.

RITCHIE, S. W.; HANWAY, J. J.; BENSON, G. O. How a Corn Plant Develops. Special Report 48. Ames, IA lowa State University. 21 p., 1993.

SACHS, P. J. D.; NEVES, C. C. S. V. J.; CANTERI, M. G.; SACHS, L. G. Escala diagramática para avaliação da severidade da mancha branca em milho. Summa Phytopathologica, v. 37, n. 4, p. 202-204, 2011.

SANTOS, M. R.; SEDIYAMA, M. A. N.; SANTOS, I. C.; SALGADO, L. T.; SANZIO, S. M. Produção de milho-verde em resposta ao efeito residual da adubação orgânica do quiabeiro em cultivo subsequente. Revista Ceres, Viçosa, v. 58, n. 1, p. 77-83, 2011. Disponível em: https://www.scielo.br/scielo. php?pid=S0034737X2011000100012\&script=sci_abstract\&tlng=pt. Acesso em: 29 jun. 2020.

SILVA, H. P. Genética da resistência a Phaeosphaeriamaydis em milho. Jaboticabal: Universidade Estadual Paulista. Tese (Doutorado). Universidade Estadual Paulista, Jaboticabal, 105f, 2002. 
SORATTO, R. P.; PEREIRA, M.; COSTA, M. T.; LAMPERT, V. N. Fontes alternativas e doses de nitrogênio no milho safrinha em sucessão à soja. Revista Ciência Agronômica, Fortaleza, v. 41, n 4, p. 511-5518, 2010. Disponível em: https://www.scielo.br/scielo.php?script=sci_ arttext\&pid=S1806-66902010000400002. Acesso em: 29 jun. 2020.

VELOSO, M. E. C.; DUARTE, S. N.; DOURADO NETO, D.; MIRANDA, J. H.; SILVA, E. C.; SOUZA, V. F. Doses de nitrogênio na cultura do milho, em solos de várzea, sob sistema de drenagem subterrânea. Revista Brasileira de Milho e Sorgo, Sete Lagoas, v. 5, n. 3, p. 382-394, 2006. Disponível em: http://rbms.cnpms.embrapa.br/index.php/ojs/article/view/200/200. Acesso em: 29 jun. 2020.

Received: June 29, 2020.

Accepted: September 17, 2020. 